\title{
Effectiveness of experiential learning-based teaching material in Mathematics
}

\author{
Mutmainah $^{1}$, Rukayah $^{2}$, Mintasih Indriayu $^{3}$ \\ ${ }^{1}$ Master Program of Elementary School Teacher Training and Education, Sebelas Maret University, Indonesia \\ ${ }^{2,3}$ Postgraduate Departement, Sebelas Maret University, Indonesia
}

\section{Article Info \\ Article history: \\ Received Oct 9, 2018 \\ Revised Oct 29, 2018 \\ Accepted Jan 6, 2019}

\section{Keywords:}

Experiential learning Mathematics cognitive ability Teaching material

\begin{abstract}
This research was aimed at finding out the effectiveness of experiential learning-based teaching material in Mathematics on the Mathematics cognitive ability of the fifth-grade student in elementary school. This research used quasi-experimental design involving two sample groups: experiment and control group. The sampling technique in this research used simple random sampling. The subject of this research was 54 students from the fifth-grade elementary school in Gunungpati Sub-district in the academic year 2017/2018. This study involved 28 students of the fifth-grade elementary school Nongkosawit 02 as the experimental group and 26 students of the fifth-grade elementary school Sadeng 03 as the control group. The instrument used in this research was multiple choice test consisting of 30 questions. The test was used to obtain pretest and posttest score. The data analysis in this research used T-independent test to examine the hypothesis. The result of the study shows the significance level of 0.000 is less than $\alpha=$ 0.05 which means that there is different cognitive ability between the experimental and control group. Thus, the use of experiential learning-based teaching material in Mathematics is effective to improve the Mathematics cognitive ability of the fifth-grade student in elementary school.
\end{abstract}

Copyright (C) 2019 Institute of Advanced Engineering and Science. All rights reserved.

\section{Corresponding Author:}

Mutmainah,

Department of Elementary School Teacher Training and Education,

Sebelas Maret University, Indonesia,

J1. Ir. Sutarmi No. 36A, Jebres, Surakarta, Jawa Tengah, Indonesia (57126).

Email: mutmainah_may@student.uns.ac.id

\section{INTRODUCTION}

Mathematics is the main subject that needs to be taught to the students since elementary school to make the student think logically, systematically, critically, and creatively. One of the Mathematics objectives as stated in Permendiknas No 22 of 2006 concerning the Content Standard states that Mathematics aims to make the students have the ability to comprehend the Mathematics concept, to explain the correlation of the concept, and to apply the concept of algorithm flexibly, accurately, efficiently, and precisely in solving the problems (Ministry of National Education, 2011). The aim is the standard that the students must attain after attending the Mathematics learning process.

The research result of Programme for International Students Assessment (PISA) in 2015 shows that Indonesia is ranked 63 out of 69 countries that have been evaluated. The rank and the average score of Indonesia is not really significant to the research result of Pisa earlier in 2012 that also put Indonesia in the category of low material mastery [1]. Other than PISA, the report of Trends in Mathematics and Science Study (TIMSS) in 2015 also shows the student ability in the elementary school in Indonesia is not satisfying yet. The result of the report published by TIMSS 2015 in December 2016 also shows the student achievement in Indonesia in Mathematics field is ranked 45 out of 50 countries. 
Based on the fact, it can be seen that the Mathematics cognitive ability of the elementary school student in Indonesia is still low compared than other countries. The low Mathematics cognitive ability is determined by many factors. One of the factors is the lack of teaching material that meets the student needs. Several improvements in the learning process and the availability of learning source are required to have the maximum result [2].

The research carried out the observation in several elementary schools in Gunungpati Sub-district. The fact found in the research field shows that the students tend to be passive and not enthusiastic in Mathematics learning process, the teaching scheme is still teacher-centered and the students only receive the learning material through the teacher's explanation since they are not supported by the Mathematics learning source that can activate and focus on the student's experience.

The Mathematics learning process in the fifth-grade of elementary school in Gunungpati Sub-district remains using the conventional teaching material which only consists of the material and the questions. The teaching material which was used directly leads to the example of the questions without being preceded by the comprehensive explanation of the concept. The provided material in the textbook is still abstract, not accompanied by the visualization of the material, and the material delivery is not interesting. Those cause poor student understanding of the material. The students ony focused on the conventional teaching material which caused the low cognitive ability. The low cognitive ability of the student is indicated by the low result of Mathematics test compared than other subjects. This problem is supported by the research conducted by Zulfiah which states that the unavailability of adequate teaching material causes low test result of the student [3].

The teaching material has the greatest role as the medium to attain Mathematics learning objective. The implementation of Mathematics learning process requires the effective teaching material. The teaching material can assist the students in learning something [4]. The effective teaching material will help the students' experience in learning activities; therefore, the Mathematics learning is more meaningful and results in improved student cognitive ability. In Mathematics learning process, the learning which directly relates the material to the real daily experiences is required. One of the teaching materials that can be used is the experiential learning-based teaching material in Mathematics. Experiential learning is developed based on Kolb's theory emphasizing the central role of the experience in learning process.

Experiential learning theory defines learning as the process whereby knowledge is created through the transformation of experience. Knowledge results from the combination of grasping and transforming experience [5]. Experiential learning reflects the learning which is attained through the personal experience and involvement [6]. Experiential learning can stimulate the student-centered learning process to make them build the experience that they get during the learning process.

Experiential learning stimulates the students in their activities to think, explore, ask, make decision, and apply what they have learned. Experiential learning-based teaching material uses student-centered approach that is started by the underlying principle that people learn best from the experience. It is in line with the research carried out by Llewellyn \& Frame which state that experiential learning is designed to give the comprehensive learning experience [7].

Experiential learning-based teaching material in Mathematics consists of four stages: Concrete Experience (CE), Reflection Observation (RO), Abstract Conceptualization (AC), and Active Experimentation (AE) [8]. Those four principles aim to make the students have the experience to experience, observe, think, and act during Mathematics learning process. Based on the above-mentioned statements, the objective that will be attained in this research is to find out the effectiveness of experiential learning-based teaching material in Mathematics on the improvement of Mathematics cognitive ability of the fifth-grade students in elementary school.

\section{RESEARCH METHOD}

This research using quasi-experimental methods, the experimental design in this research is the matching only pretest-posttest control group design [9]. Because this research to find out the effectiveness of experiential learning-based teaching material in Mathematics on the improvement of Mathematics cognitive ability of the fifth-grade students, then need a balanced condition between the experimental and the control group before the subject treatment. After to know two groups status is homogeneous, the experiment group is given the treatment using experiential learning-based teaching material, while the control group is given the treatment without experiential learning-based teaching material.

This research was conducted in two elementary schools in Gunungpati, Semarang, Indonesia. Sampling techniques in this research was simple random sampling. The subject in this research was 54 fifthgrade elementary school students in Gunungpati 2017/2018 school year. The data source in this research was the scores of tests obtained by the students, either the experimental group or the control group.

Int. J. Eval. \& Res. Educ. Vol. 8, No. 1, March 2019: 57 - 63 
The research data were collected by using test. Analysis test in this research was using ITEMAN software with validity and reliability using significance 5\%. The tests used are 30 multiple choice question. Result all tests in this research is valid, because more than 0.2787 . Value of reliability test using ITEMAN software gained 0.730 so the test of reliability. This test was used to measuring the student cognitive ability before and after using experiential learning-based teaching material in Mathematics.

The tests used in this research were pre-test and post-test to the control group and experiment group. The results of the test were analyzed by using Independent $t$-test in where $t_{\text {obtained }}$ was compared with $t_{\text {table. If }}$ $t_{\text {obtained }}>t_{\text {table }}$ hypothesis is accepted $\left(\mathrm{H}_{0}\right.$ rejected), if $t_{\text {obtained }}<t_{\text {table }}$ rejected $\left(\mathrm{H}_{0}\right.$ accepted). Formula independent t-test is:

$$
t=\frac{\left(\bar{X}_{1}-\bar{X}_{2}\right)}{s_{p} \sqrt{\frac{1}{n_{1}}+\frac{1}{n_{2}}}}
$$

\section{RESULTS AND DISCUSSION}

The data of this research was obtained by distributing the questions of pretest and posttest to the experimental and control group. The result of pretest and posttest is analyzed to find out the effectiveness of experiential learning-based teaching material in Mathematics on the student cognitive ability of the fifthgrade elementary school in Gunungpati Sub-district. The student cognitive ability is one of the indicators when the learning process runs well. The cognitive ability in Indonesia can be stated as successful if the student passes the Minimum Passing Grade (KKM) that has been determined [10]. KKM in Mathematics subject for the fifth-grade student in Gunungpati Sub-district is 60. The data for the pretest and posttest result of the student cognitive ability is shown in Table 1.

Table 1 shows that there is significant difference between the pretest and posttest score of the experimental and control group. The pretest average score of the experimental group is 44.29 and the posttest score is improved to 75.71. Meanwhile, the pretest average score of the control group is 42.95 and the posttest score is improved to 63.72. In posttest, the score of the experimental group is higher than the posttest of the control group. Most of the students in experimental group has passed KKM, while several students in the control group have not passed KKM.

In addition to the pretest and posttest score of the experimental and control group, this research also provides the calculation data of the hypothesis test of pretest and posttest group in experimental and control group. The hypothesis test in this research was conducted to find out the effectiveness of the use of experiential learning-based teaching material in Mathematics whether or not there is the difference between experimental group that used experiential learning-based teaching material in Mathematics and the control group that did not experiential learning-based teaching material in mathematics. Before carrying out the hypothesis test, balance test was done earlier to the experimental group and the control group.

Balance test was aimed at finding out whether or not the experimental group and the control group are in the balanced situation. The data that were used in balance test is the data of pretest score of the experimental and control group. Before calculating the balance test, the prerequisite test was done to the experimental and control group. The prerequisite test consists of normality test and homogeneity test. The result of prerequisite test of the pretest score in experimental and control group is shown in Table 2.

Table 1 . The pretest and posttest result of the student cognitive ability

\begin{tabular}{lllll}
\hline \multicolumn{1}{c}{ No } & \multicolumn{2}{c}{ Experiment } & Control \\
& Pretest & Posttest & Pretest & Posttest \\
\hline Mean & 1240 & 2120 & 1117 & 1657 \\
Average & 44.29 & 75.71 & 42.95 & 63.72 \\
Min & 30 & 60 & 23 & 47 \\
Max & 57 & 87 & 57 & 80 \\
Median & 45 & 78 & 45 & 65 \\
\hline
\end{tabular}

Table 2. Prerequisite test result

\begin{tabular}{|c|c|c|c|c|}
\hline & The tests done & Test type & Sig. & Test decision \\
\hline \multicolumn{5}{|c|}{ prerequisite test } \\
\hline a. & Normality test & $\begin{array}{l}\text { Kolmogrov- } \\
\text { Smirnov }\end{array}$ & & \\
\hline & Pretest & & 0.819 & $\mathrm{H}_{0}$ accepted \\
\hline & Posttest & & 0.644 & $\mathrm{H}_{0}$ accepted \\
\hline b. & Homogenity test & Levene's test & 0.431 & $\mathrm{H}_{0}$ accepted \\
\hline
\end{tabular}

The effectiveness of the use of experiential learning-based teaching material in mathematics (Mutmainah) 
Table 2 shows that the distribution of the pretest score data in the experimental and control group is normal and homogenous. It is shown in the result of normality test and homogeneity test. The normality test was calculated using kolmogrovsmirnov. In pretest, the experimental group got the significance level of 0.819 ( $\mathrm{Sig}>0.05)$, so H0 is accepted which means that the distribution of the pretest score in experimental group is normal. Meanwhile, the pretest in control group got the significance level of 0.644 (Sig. $>0.05$ ), so Ho is accepted which means the distribution of the pretest score in control group is normal.

The homogenity test of the pretest in experimental and control group was analyzed using Levene's Test. The significance level in homogeneity test is 0.431 ( $\mathrm{Sig} .>0.05$ ), so H0 is accepted which means that the pretest scores of the experimental and control group are homogeneous. After the prerequisite test, the balance test was conducted. Balance test used Independent T-test. The result of the balance test is shown in Table 3.

Table 3. Independent $\mathrm{T}$ test results

\begin{tabular}{ccc}
\hline Test Type & Sig. & Test decision \\
\hline Independent Sample T-Test & 0.600 & $\mathrm{H}_{0}$ accepted \\
\hline
\end{tabular}

The balance test between the experimental and control group used independent sample t-test. The significance level is 0.600 ( $\mathrm{Sig}$. $>0.05$ ) which means that $\mathrm{H} 0$ stating that there is no difference in pretest score between experimental and control group is accepted. It indicates that both groups have the balanced initial cognitive ability.

Based on the balance test, both groups have the balanced cognitive ability. Afterward, the hypothesis test was conducted to find out the effectiveness of the products being developed. The effectiveness test is based on the improvement of the Mathematics cognitive ability of the students in experimental and control class after being given the different treatment. It can be seen from the difference of the pretest and posttest of the two groups ( $\mathrm{N}$ gain). If the data of $\mathrm{N}$ gain from the experimental and the control group are distributed as normal and homogenous, the hypothesis test will be used which is the independent T-test. The result of prerequisite test of the experimental and control group is shown in Table 4.

Table 4 shows the score data of $\mathrm{N}$ gain of the experimental and control group which are distributed normal and homogenous. It is indicated by the result of normality test and homogeneity test as the prerequisite test. The normality test in this effectiveness test is analyzed using kolmogrov-smirnow. The experimental group obtained the significance level of 0.504 (Sig. > 0.05), so H0 stating that $\mathrm{N}$ gain of the experimental group is distributed normally. The $\mathrm{N}$ gain of the control group obtained the significance level of 0.084 (Sig. > 0.05), so $\mathrm{H} 0$ stating that the value of $\mathrm{N}$ gain of the control group is also distributed normally is accepted.

The homogenity test of the experimental and control group in this effectiveness test was analyzed using Levene's test. The significance level of the homogeneity test was 0.205 (Sig. $>0.05$ ), so H0 stating is accepted which states that $\mathrm{N}$ gain of the experimental and control group is homogenous. After the prerequisite test, the effectiveness test was conducted using independent sample t-test. The result of $\mathrm{T}$ independent test is shown in Table 5.

Table 4. Result of N-gain prerequisite test.

\begin{tabular}{|c|c|c|c|}
\hline The tests done & Test type & Sig. & Test decision \\
\hline \multicolumn{4}{|l|}{ prerequisite test } \\
\hline a. Normality test & Kolmogrov-Smirnov & & \\
\hline Pretest & & 0.504 & $\mathrm{H}_{0}$ accepted \\
\hline Posttest & & 0.084 & $\mathrm{H}_{0}$ accepted \\
\hline b. Homogenity test & Levene's test & 0.205 & $\mathrm{H}_{0}$ accepted \\
\hline
\end{tabular}

Table 5. Independent T-Test of N-gain

\begin{tabular}{cccc}
\hline Test Type & tcount & Sig. & Test Decision \\
\hline Independent Sample T-Test & 6.321 & 0.000 & $\mathrm{H}_{0}$ rejected \\
\hline
\end{tabular}

The result of independent sample t-test obtained the significance level of 0.000 (Sig. $>0.05$ ), so it can be concluded that $\mathrm{HO}$ is rejected which states that there is no different score between the experimental and control group after being given the different treatment. In posttest, the score of the experimental group is higher than the control group. Therefore, it can be concluded that the experiential learning-based teaching material in mathematics is effective to improve the Mathematics cognitive ability in the experimental group.

Int. J. Eval. \& Res. Educ. Vol. 8, No. 1, March 2019: 57 - 63 
Based on the result of the research, it indicates that the experiential learning-based teaching material in Mathematics is effective to improve the student Mathematics cognitive ability. The effectiveness of the experiential learning-based teaching material in Mathematics is shown in the improvement of the Mathematics cognitive ability in the experimental group after using the teaching material product. The effectiveness of the experiential learning-based teaching material in Mathematics can be seen in the statistical calculation using independent $t$-test. Independent $t$-test from the pretest and posttest result in the experimental and control group has the significance level of 0.000 which is less than $\alpha=0.05$. Thus, H0 stating that there is different cognitive ability between the experimental and control group is rejected.

The difference can be seen based on the mean of posttest score in the experimental and control group. The experimental group that used experiential learning-based teaching material in Mathematics has the mean that is higher than the control group that used the common teaching material in Mathematics learning process. The mean of posttest score in experimental group is 75.71, while the mean of the posttest score in control group is 63.72. It indicates that the cognitive ability of the experimental group is better than the control group.

The teaching material is one of the factors that has the great role in determining the success of the teaching and learning process [11]. Mathematics learning using learning-based teaching material is more effective as it involves the students actively during the learning process. The experience-based learning can make the students active [12]. The experience-based learning generates the benefits in integrating the theory, research, and practice to the students' skills in the real life. Experiential learning has the effect on the improvement of the learning success [13].

Experiential learning-based teaching material in Mathematics has four principles: Concrete Experience (CE), Reflection Observation (RO), Abstract Conceptualization (AC), and Active Experimentation (AE). First, the concrete experience that is provided as the teaching material is aimed at making the students fully involve themselves in the new experience. The concrete experience is provided as the teaching material by displaying the picture illustration which is suitable to the material. The picture in the teaching material can clarify the material content, increase the attractiveness, and reduce the students' boredom to understand the material [14]. Second, the reflection observation is aimed at making the students able to observe and reflect or think about the experience from various points of view. It is underlain by the value of experiential learning activity is increased by asking the students to reflect on heir new experience and explore various implication [15]. In this stage, the students learn by observing and listening even observing more carefully before drawing the conclusion of their own thought [16]. Third, the conceptualization stage is aimed at making the students create the concept that integrates the observations to become the comprehension of the material being studied. Fourth, the implementation stage is aimed at making the students apply the material that has been taught to solve the problems which are related to the material. Those four principles aim to make the students have the ability to experience, observe, think, and act during Mathematics learning process.

Experiential learning emphasizes the process in which the students are learning by doing which is based on the assumption that the student will more comprehend the material if they are actively involve in the material compared than they only listen to the lecture or read certain material [17]. Experiential learningbased teaching material encourages the student-centered learning process. Therefore, the students can build their own knowledge from the experience that they get during the learning process. Experiential learning concerns more on process rather than the result. The students are involved directly in the learning process. It is in line with the statement of Geh stating when someone learns from his or her own experience, the learning becomes meaningful [18]. How the student obtains and change their experience is very important for the learning process.

Based on the result of the research that has been conducted, experiential learning-based teaching material in Mathematics being developed is effective in improving the student cognitive ability of the fifthgrade elementary school. The effectiveness of the use of experiential learning-based teaching material in Mathematics in improving the student cognitive ability is supported by the relevant researches. The researches carried out by Amir, et al [19], and Woo [20] prove that the learning which uses the teaching material can improve the student learning result. The researches which also conducted by Tanaka, et al. [21], Matias and Gonzalez [22], Arthur and Raine [23], and Judge, et al. [24] prove that experiential learning can give the good opportunity for the students and the student will be interested in the learning process since they are given the concrete examples in the daily life. In addition, the research conducted by Sholihah [25] also proves that the positive effects of experiential learning are created since it can attract and challenge someone to learning so it also creates the motivation that further will affect the learning process. The students using experiential learning-based teaching material in Mathematics in their schools tend to have the higher cognitive ability than the students that do not use experiential learning-based teaching material in Mathematics in their school.

The effectiveness of the use of experiential learning-based teaching material in mathematics (Mutmainah) 


\section{CONCLUSION}

Based on the result of analysis and discussion, it can be concluded that the use of experiential learning-based teaching material in Mathematics is proven effective in improving the Mathematics cognitive ability of the fifth-grade students in the volume of cube and beam. It is proven by the result of t-test in the experimental and control group which obtains the significance level of 0.000 which is less than $\alpha=0.05$. So, H0 stating that there is different cognitive ability between the experimental and control group is rejected. The mean of posttest score in the experimental group is higher than the control group. Therefore, the use of experiential learning-based teaching material in Mathematics is effective in improving the Mathematics cognitive ability of the fifth-grade students.

Based on the research that has been conducted, it is suggested to (1) the teacher that should implement the experiential learning-based teaching material in Mathematics that has been previously developed, (2) the student that is expected to be able actively in comprehending the material and to improve the cognitive ability using experiential learning-based teaching material in Mathematics, (3) the other researchers that can use this research as the reference for the similar research related to the development of experiential learning-based teaching material in Mathematics.

\section{REFERENCES}

[1] OECD-PISA. "Assessing Scientifc, Reading and Mathematical Literacy: A Framework for PISA," 2015.

[2] Gazali, R.Y., "The development of learning materials for mathematics for junior high school Students based on Ausubel's theory of Learning," Pythagoras: Mathematics Education Journal, vol. 11(2), pp. 182-192, 2016.

[3] Zulfiah, A., "The development of Cooperative Learning Device Type Stad with Scramble Method on Material coordinate system," Journal Of Educational Research, vol. 34(2), pp. 105-112, 2017.

[4] Hamdani. "Teaching And Learning Strategies," Bandung: CV Pustaka Setia, 2011.

[5] Kolb, D. "Experiential Learning," New Jersey : Prentice-Hall, 1984.

[6] Loura, I.C., "Application of The Experiential Simulation Learning Approach (ELSA) Model to Teach Sustainability to International Business Management Undergraduate Students," Journal of Management Development, vol. 33(6), pp. 620-636, 2014.

[7] Llewellyn, A. \& Frame, S., "Online Experiential Learning: Bridging The Gap Between Theoretical Knowledge and Realworld Competence," Development and Learning in Organizations: An International Journal, vol.27(1), pp. 16-18, 2012.

[8] Kolb, D., "Experiential Learning," New Jersey : Prentice-Hall, 1984.

[9] Sugiyono. "Educational Research methods (Quantitative, qualitative Approach, and R\&D)," Bandung: Alfabeta, 2015.

[10] Mardapi, et al., "Determine The Minimum Ketuntasan Criterion-Based Learners," Journal of research and evaluation in Education, vol. 19(1), pp. 38-45, 2015.

[11] Lestari, I., "Competency-Based Learning Materials Development." Padang: Akademia Permata, 2013.

[12] Judge, L.W. et al. "Engaging Experiential Service Learning Through A Co-Curricular Club: The Chase Charlie Races," International Council for Health, Physical Education, Recreation, Sport, and Dance Journal of Research, vol. 6(2), pp. 30-38, 2011.

[13] MacDonald, K. \& Gibson, C.E. "Your Tutor Is Your Friend: Using Experiential Learning To Enhance Second Year Transition," Journal of Applied Research in Higher Education, vol. 3(2), pp. 107-115, 2011.

[14] Prastowo, A., "The Creative Guide Makes Innovative Learning Materials," Yogyakarta: Diva Press, 2012.

[15] Silberman, M., "Handbook Experiential Learning: Learning strategies from the real world. Translate by Khozim, M.," Bandung: Nusamedia, 2014.

[16] Wicaksono, et al., "The effectiveness of a Model of Experiential Learning to improve Exploration and commitment Careers in high school students," Journal of education: theory, research, and development, vol. 3(6), pp. 783-787, 2018.

[17] Balich, R. et al., "Year Two: The Impact Of Addictions Education and Experiential Activities On Attitudes Of Students," Journal of Applied Research in Higher Education, vol. 7(1), pp. 68-82, 2015.

[18] Geh, E.Z., "Organizational Spiritual Leadership Of Worlds "Made" and "Found": An Experiential Learning Model For "Feel"," Leadership \& Organization Development Journal, vol. 35(2), pp. 137-151, 2014

[19] Amir, M. Muris, \& Arsyad, M., "Development of Device physics-based Learning experiences on Learners NinthClass Science high school 9 Pinrang," Journal of science and physics education, vol.11(3), pp. 202-213, 2015.

[20] Woo, T.K., "Developing Quality Learning Materials for Effective Teaching and Learning in an ODL Environment: Making The Jump From Print Modules To Online Modules," Asian Association of Open Universities Journal, vol. 6(1), pp. 51-58, 2011.

[21] Tanaka, K. et al.. "Learning How to Learn Through Experiential Learning Promoting Metacognitive Skills to Improve Knowledge Co-creation Ability," Journal International Procedia Computer Science, vol. 9(10), pp. 146-156, 2016.

[22] Matias, A. \& Gonzalez, A.A., "What Do Geology And It Have In Common'? The Case Of An International Collaboration Through Experiential Learning," Journal of Innovation in Higher Education Teaching and Learning, vol. 9, pp. 107-127, 2017.

Int. J. Eval. \& Res. Educ. Vol. 8, No. 1, March 2019: 57 - 63 
Int. J. Eval. \& Res. Educ.

[23] Arthur, A.D. \& Raine, J.W., "Experiential Learning and Teaching At A Distance: How Distinctive An Experience?," Journal of Developing Public Managers for Changing World, vol. 5(1), pp. 141-159, 2017.

[24] Judge, L.W. et al., "Engaging Experiential Service Learning Through A Co-Curricular Club: The Chase Charlie Races," International Council for Health, Physical Education, Recreation, Sport, and Dance Journal of Research, vol. 6(2), pp. 30-38, 2011.

[25] Sholihah, M. et al., "Influence Model Of Experiential Learning Towards Thinking Ability High School Students," Journal of education: theory, research, and development, vol. 1(11), pp. 2096-2100, 2016.

The effectiveness of the use of experiential learning-based teaching material in mathematics (Mutmainah) 